
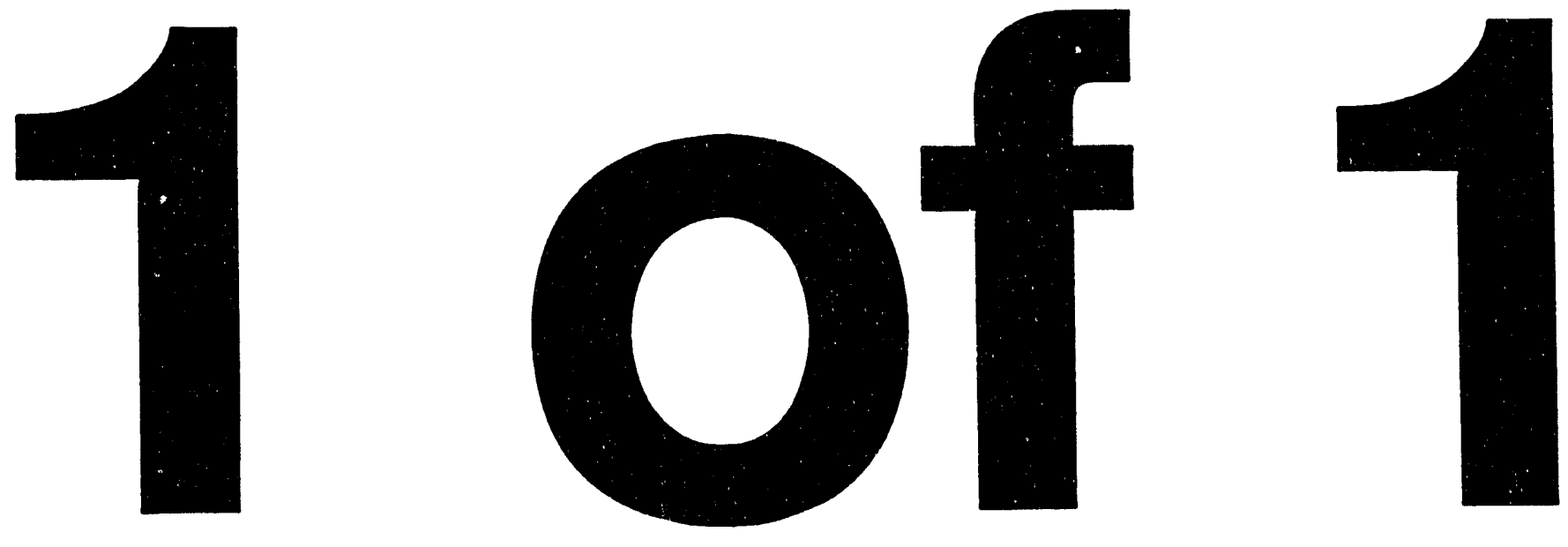


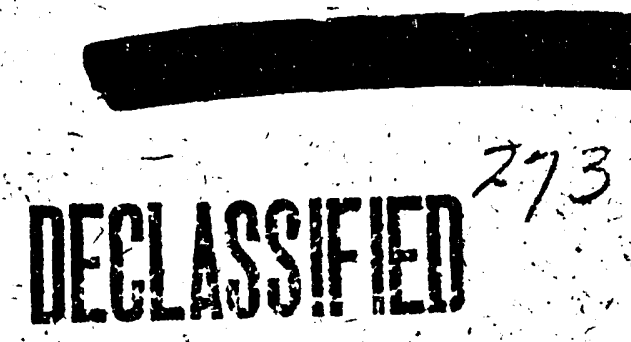

\section{HEAT GENERATION IN STORED REDOX WASTES}

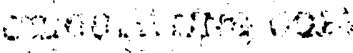

aroso:

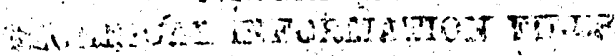

THIS DOCUMENT HAS BEEN SCANNED

AND IS STORED ON THE OPTICAL DISK DRIVE

BY

J. S. KANE AND R. E. BURNS

TECHNICAK SECTION

ENGINEERING DEPARTMENT

DECLUSSFIED

SEPTEMEER 2, 1952

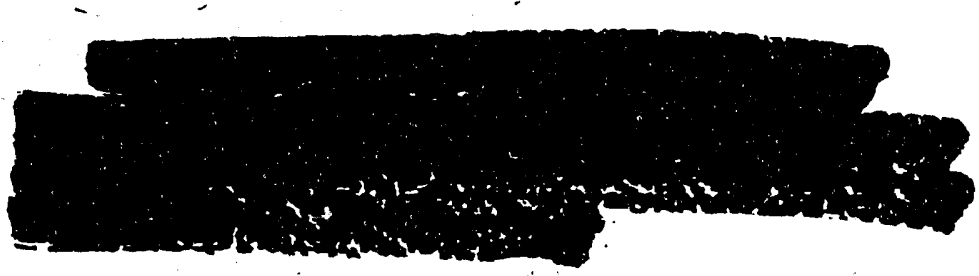

NUCLEONICS DIVISION RICHLAND, WASHINGTON

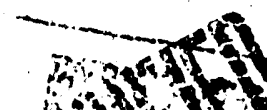

(1) 14 . GENERAL (960) ELETRIC - 


\section{DECLLSSFFED}

$\mathrm{HW}-23477$

Security Information

Technology - Hanford Processes

This document consists

of 15 pages.

HEAT GENERATION IN STORED REDOX WASTES

By

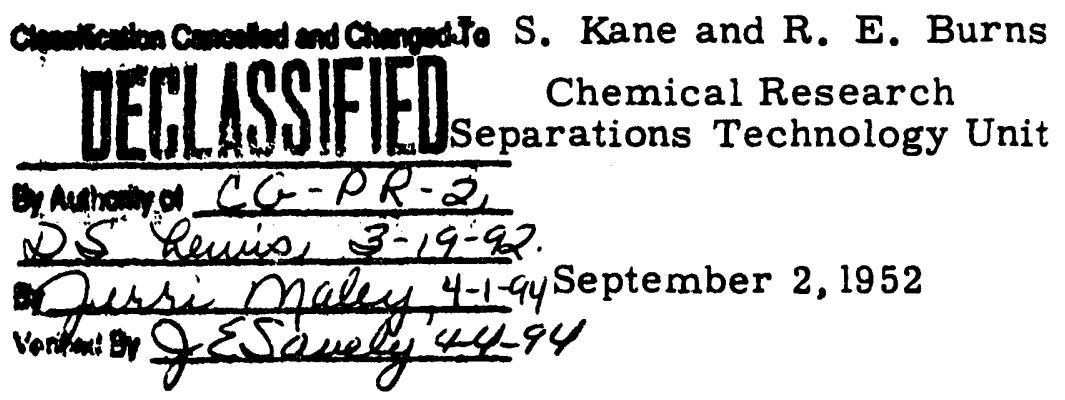

HANFORD WOR KS

RICHLAND, WASHINGTON

Operated for the Atomic Energy Commission by the General Electric Company under Contract \# W-31-109-Eng-52
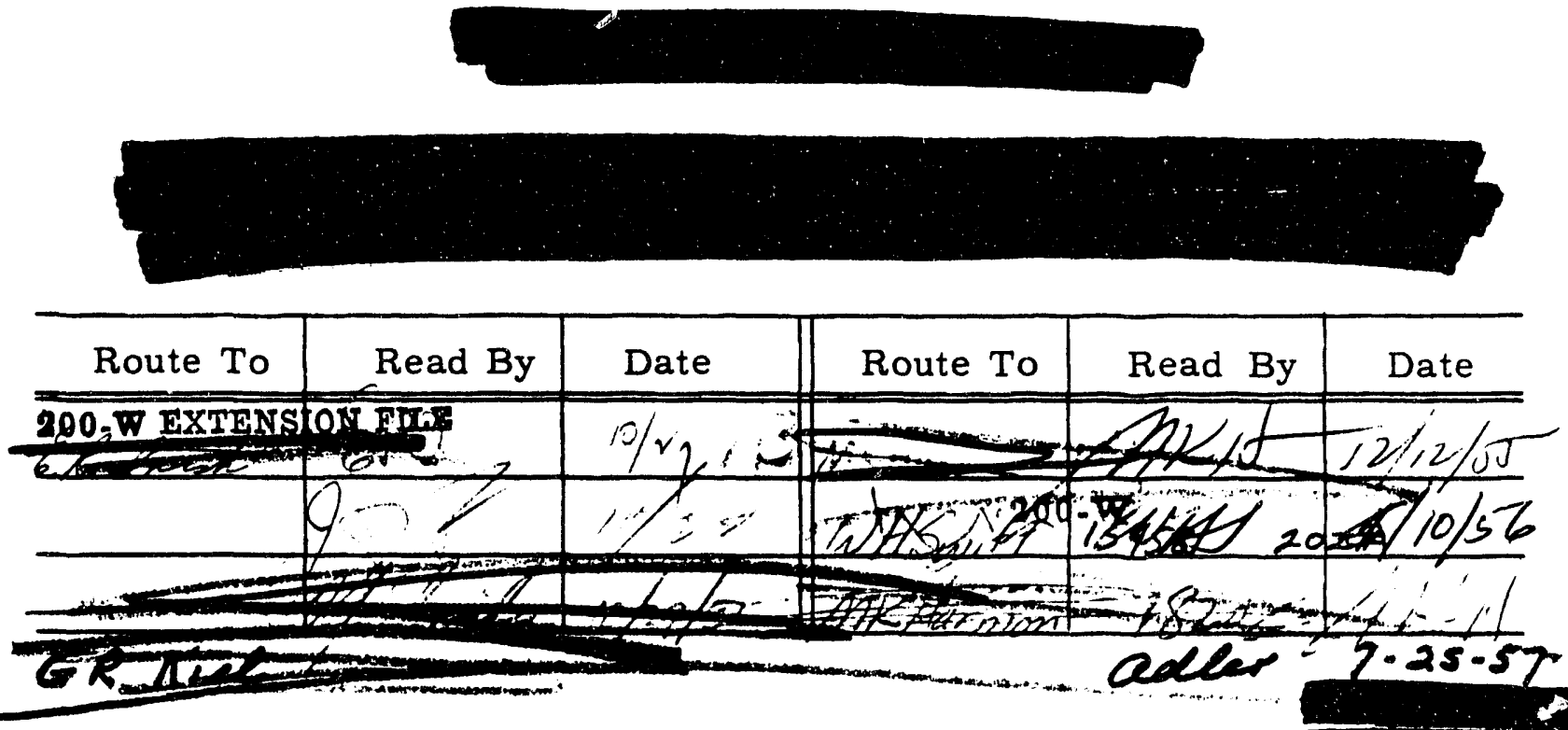


\title{
DECLLASSFFED
}

\author{
$-2-$ \\ HW -23477 \\ Technology - Hanford Processes
}

COPY NUMBER

INTERNAL DISTRIBUTION

A. B. Greninger

O. H. Greager - W. K. Woods

R. B. Richards

W. I. Patnode

W. K. MacCready

F. W. Woodfield

r. E Tomlinson

E. R. Irish

R. H. Beaton

C. A. Rohrmann

W. B. Webster

H. A. Carlberg

F. A. Hollenback

W. N. Mobley

J. S. McMahon

H. E. Hanthorn

H. H. Hubble

G. W. Watt, University of Texas

O. F. Hill

R. E. Burns

300 File

700 File

Pink Copy

Yellow Copy

EXTERNAL DISTRIBUTION

41

$42-56$

Atomic Energy Commission, Washington Chicago Patent Group duPont Company Hanford Operations Office Knolls Atomic Power Laboratory Patent Branch, Washington Savannah River Operations Office (Augusta) Savannah River Operations Office (Wilmington) Technical Information Service, Oak Ridge 
HW -23477

\begin{abstract}
Fission product activities and heat generated by fission product decay as a function of time, in waste solutions obtained by processing uranium irradiated under the present Hanford schedule, were calculated. From these data, curves showing expected heat evolution in stored Redox Process Wastes, during and following filling of the waste tanks, were prepared assuming various modes of operating the plant and various production rates. Total heat available for evaporation of water from the tanks was also determined.

Under the most favorable plant operating conditions considered, calculated heat available for evaporation will be sufficient to reduce the waste volume by a factor of two. Experimental work showed that the wastes may be reduced in volume (evaporation) by a factor greater than four. Thus, supplemental heat would be required to attain the maximum volume reduction.
\end{abstract}




\section{HEAT GENERATION IN STORED REDOX WASTES}

\section{INTRODUCTION}

The subject of heat generation in waste solutions resulting from the processing or irradiated uranium has been discussed by several

authors $(1,2,3)$. However, significant increases in pile power level, and megawatt days of irradiation per ton on uranium have become standard practice at Hanford since these reports were issued. To provide information directly applicable to the irradiated uranium which will be processed in the Redox Plant at Hanford, curves relating heat generation from radioactive decay of fission products to cooling time for uranium irradiated under the present Hanford schedule have been derived by calculation. Also, curves relating instantaneous heat evolution to time in the stored aqueous wastes which will result from operation of the Redox Plant have been derived.

Since the calculated heat evolution from radioactive decay within the stored Redox wastes is sufficient to evaporate significant quantities of water, evaporative concentration of the aqueous wastes in the storage tanks was suggested. Experiments to determine the possible concentration of the stored wastes were performed.

\section{SUMMARY}

The calculations made indicate that sufficient heat evolution from radioactive decay may occur in the Redox waste storage tanks to evaporate significant quantities of water from the tanks. Experimental work showed that considerable volume decrease of the stored waste by evaporation is possible, a volume reduction factor between three and four being necessary to remove essentially all of the unbound water. Under no mode of operating the Redox plant considered was the calculated available heat in the waste storage tanks sufficient to achieve the maximum volume reduction factor of the wastes. Depending on the megawatt days of irradiation per ton of uranium, cooling time before processing the uranium, number of 


\section{DECLLSSFFED}

tons processed per day, and the number of uranium and plutonium cycles operated, heat derived from fission product decay could reduce Redox waste volumes by 20 to 50 per cent. Supplemental heaf would be required to attain the maximum possible volume reduction of at least 75 per cent.

\section{CALCULATIONS OF HEAT EVOLUTION}

For this study, all fission products having half-lives in excess of eight days and a fission yield greater than 0.5 per cent were considered, with the exception of those isotopes expected to be gaseous and therefore evolved during the dissolution of the irradiated uranium. Fission yields and decay schemes were taken from a report by P.R. Gilette ${ }^{(4)}$ and from the National Bureau of Standards review of nuclear data ${ }^{(5)}$. Since one fission of $\mathrm{U}^{235}$ generates $197 \mathrm{Mev}$ of energy, one joule or watt-second corresponds to $3.17 \times 10^{10}$ fissions. A power level of 2.2 megawatts per ton of uranium is, then, equivalent to $6.97 \times 10^{16}$ fissions per second per ton. This value was used in the calculations. Activities generated in the uranium during irradiation and present in the uranium or in solutions derived from its processing at various cooling times were calculated by standard equations available in most texts on radioactivity. In calculating the heat generated by radioactive decay it was assumed that all gamma energy is absorbed to produce heat and that the effective energy from beta emission is equal to 0.4 of the maximum beta energy for the nuclide in question.

Table I shows the activity in curies of the various nuclides considered, and the energy in watts generated by decay of these nuclides, per ton of uranium as a function of cooling time, after irradiation to 600 megawatt days per ton at a power level of 2.2 megawatts per ton. Figure 1 presents these same data graphically.

Since the heat generated by radioactive decay of the fission products from a particular sample of irradiated uranium varies with time, the instantaneous evolution of heat by stored wastes from a process such as

\section{DECLASSIFIED}


売|

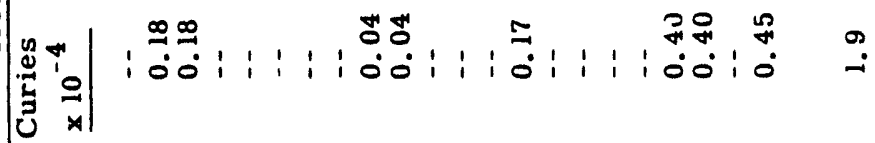
营

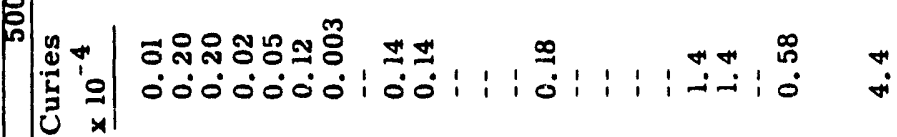
号| 至| .

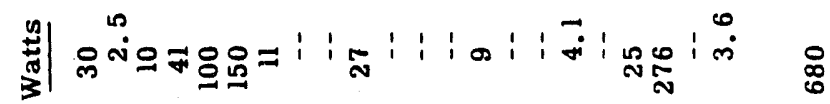

至|

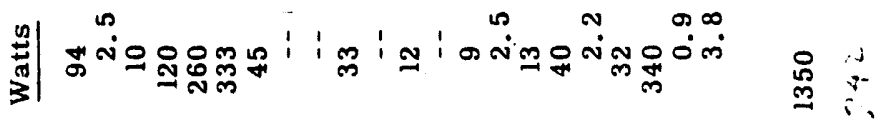

\&

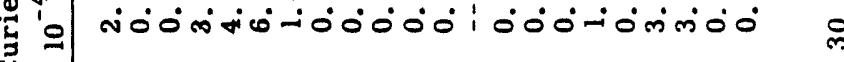

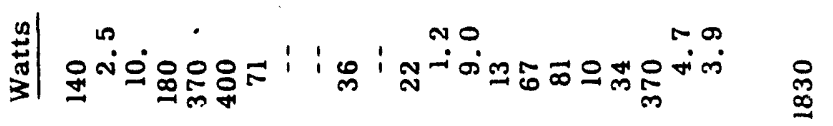

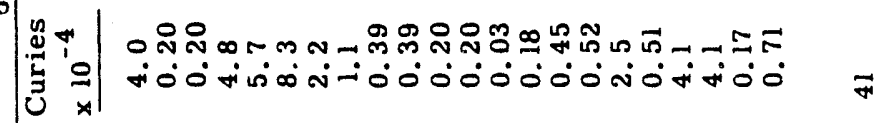

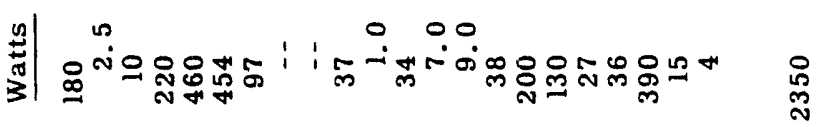

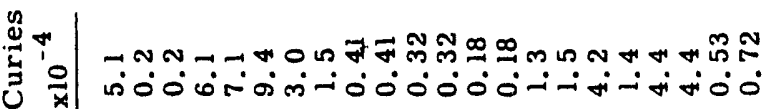

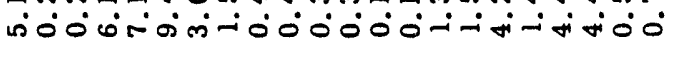

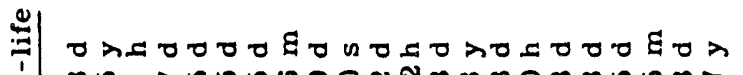

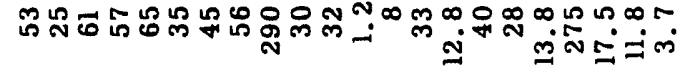

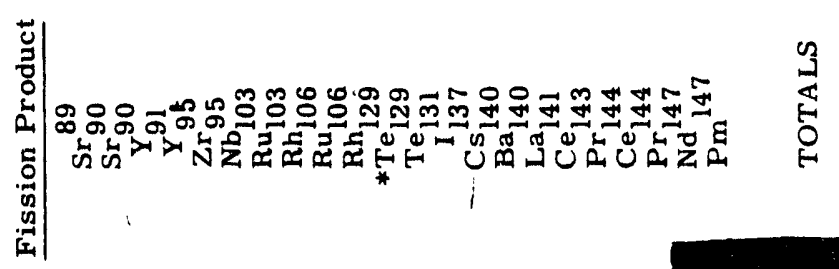




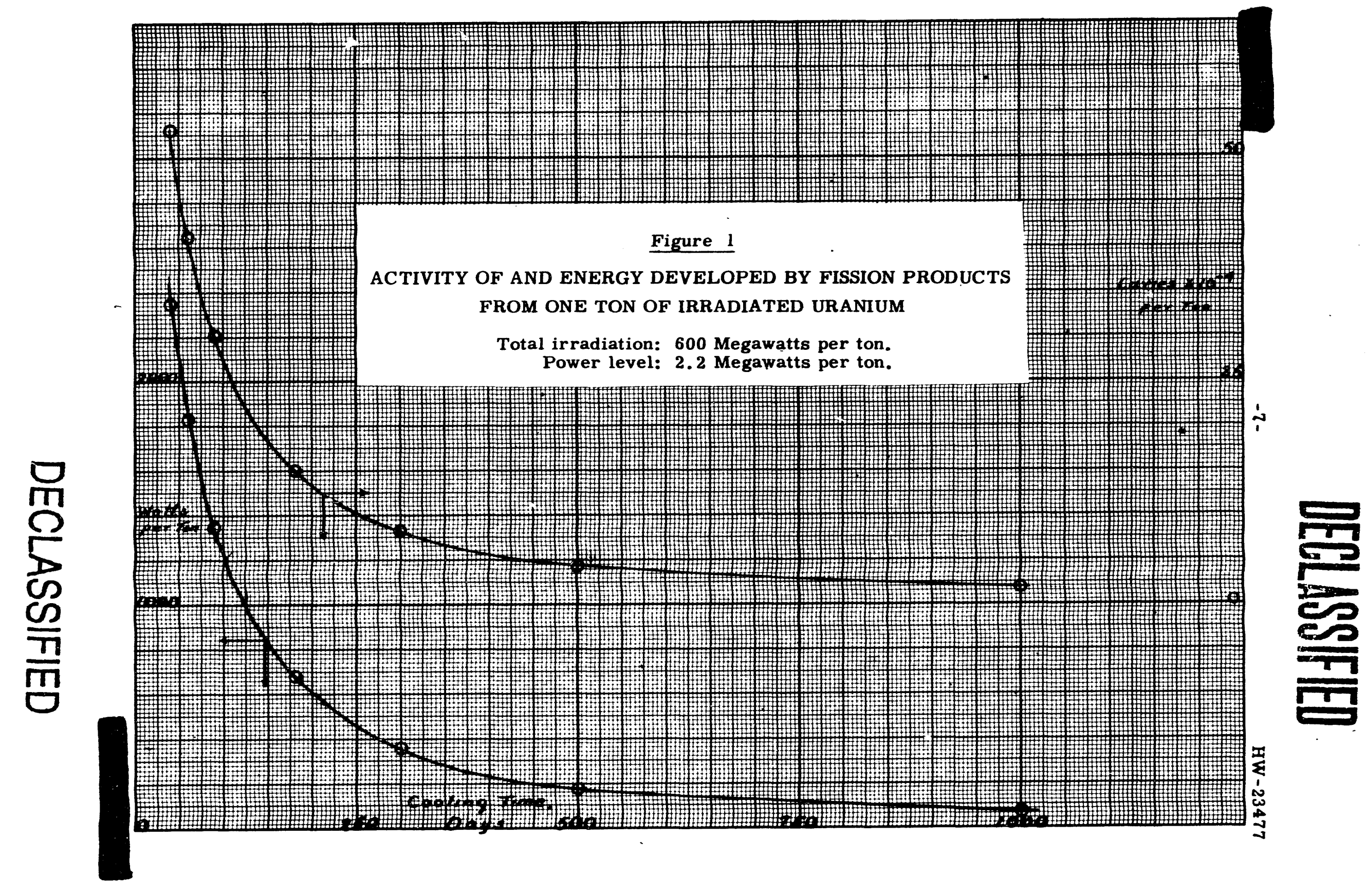




\section{DECLLSSFFED}

Redox will vary with cooling time of the uranium when processed as well as with the rate at which a particular waste tank is filled. Although the Redox plant is constructed to operate on three uranium and three plutonium cycles, there is hope that product specifications may be met by operating less cycles for both uranium and plutonium. In this case less waste would be stored per ton of uranium processed, a given waste tank would be filled more slowly but would receive fission products from more tons of uranium. Also, the rate of uranium processing (tons per day) will influence the rate at which a given waste tank is filled. Using the data given in Figure 1 for uranium irradiated to 600 megawatt days per ton at 2.2 megawatts per ton, curves were constructed showing the expected instantaneous heat evolution in a 750,000 gallon tank receiving wastes from a Redox Plant during and following filling of the tank. Processing rates of 2.5 and five tons of uranium per day were considered, as well as operating the plant on $2 \mathrm{U}-2 \mathrm{Pu}$ cycles and $3 \mathrm{U}-3 \mathrm{Pu}$ cycles. It was considered that the irradiated uranium would be cooled 60 days before processing. Volumes of waste stored per ton of uranium processed were taken from the Redox Technical Manual ${ }^{(6)}$. These curves are shown in Figure 2. Similar curves shown in Figure 3, were constructed from Figure 1 for wastes produced after a cooling time of only 40 days.

Experience already gained in the storage of Metal Waste from the Bismuth Phosphate Process indicates that sufficient heat may be generated in Redox waste tanks to cause their contents to boil. Accurate data on the rate of heat loss from the storage tanks to the ground is not available. R. E. Tomlinson states a value of $250,000 \mathrm{Btu}$ 。 per hour as the heat loss from a 500, 000 gallon tank when the contents are near the boiling point $(7)$, This value was obtained by relating tank temperature to calculated heat evolution rate for certain Bismuth Phosphate Process Metal Waste Tanks whose contents have approached boiling. More recently a value of 360,000 Btu. per hour has been obtained for the heat loss from a 750, 000 gallon tank such as will be used for the storage of Redox Wastes ${ }^{(8)}$. 


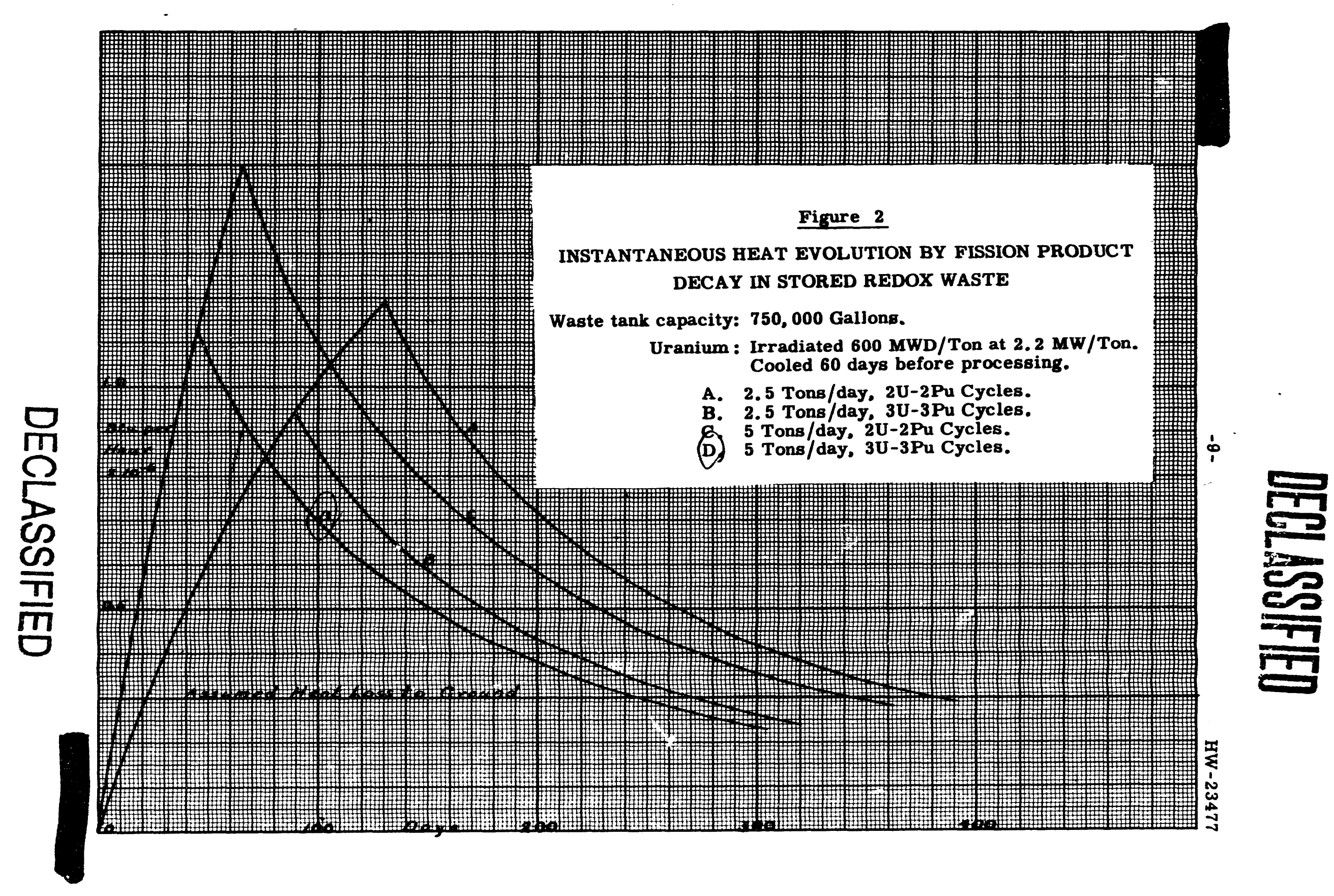




\section{DECLASSFIED}

$-10-$

HW - 23477

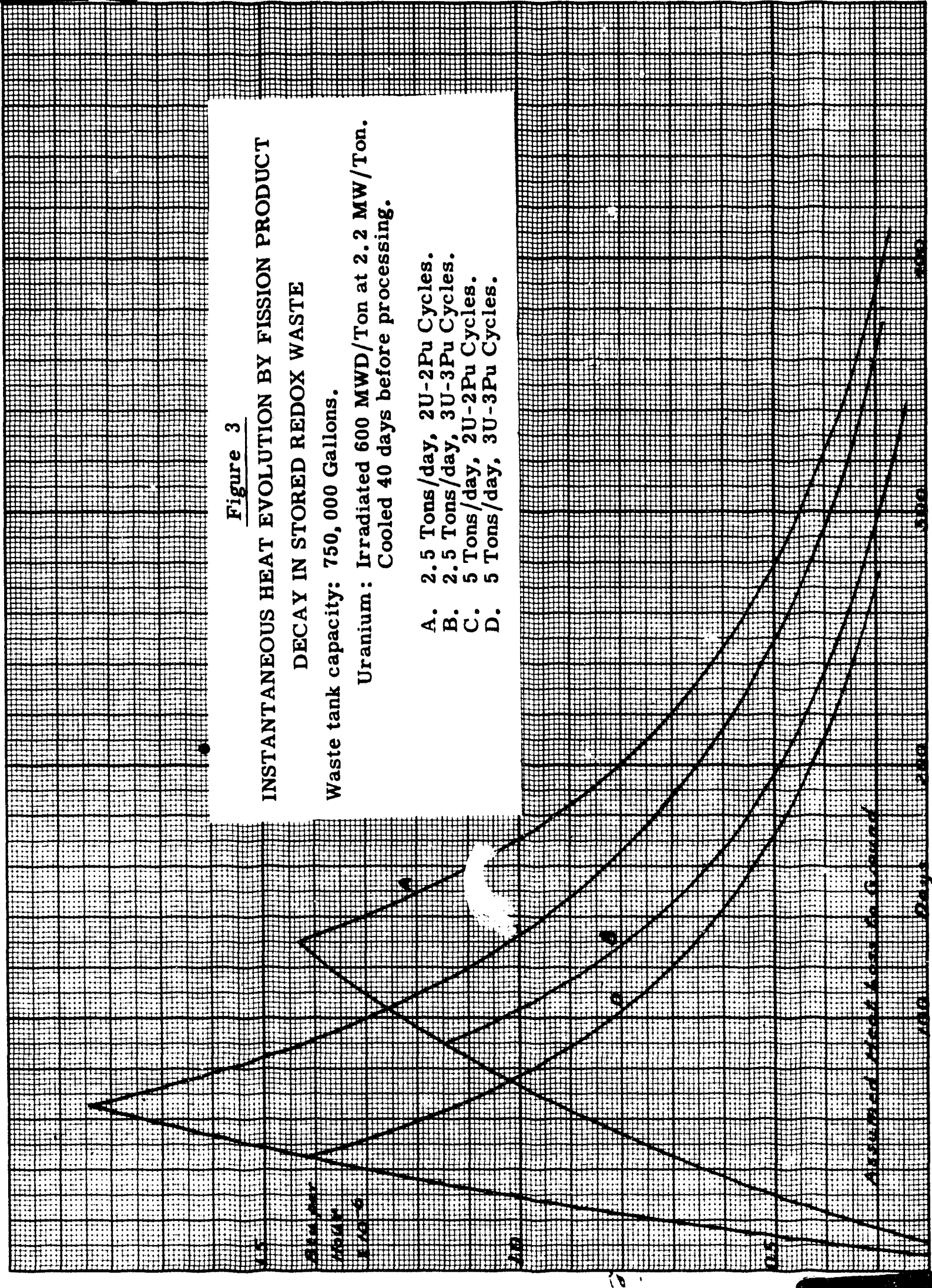

DECLASSIFIED 
Part of the purpose of making the calculations included in this report was to determine whether or not sufficient heat will be generated by fission product decay within the storage tanks to evaporate significant quantities of water and thus accomplish a volume reduction of the stored waste. For this purpose the data shown in Figures 2 and 3 were used. It was assumed that about 300,000 Btu. per hour will be lost to the ground from a 750, 000 gallon tank when the contents are at the boiling point and that all heat in excess of this quantity will be available for evaporation of water. It was further assumed that the contents of a tank would reach the boiling point at the same time the tank was filled. This latter may be a conservative estimate in some cases and pessimistic in others. Graphically, the area under the instantaneous heat evolution curves such as those shown in Figures 2 and 3 above the 300,000 Btu. per hour line and to the right of the maximum neat evolution (time tank is filled) was considered as the total heat available for the evaporation of water from the tanks. Areas under these curves were obtained by graphical integration. Table II shows the quantity of water which, according to these assumptions, could be evaporated by fission product decay by a tank of stored Redox waste produced under a variety of production conditions. 
TABLE II

CALCULATED EVAPORATION OF WATER. FROM REDOX WASTE STORAGE TANKS

\begin{tabular}{|c|c|c|c|c|c|}
\hline $\begin{array}{l}\text { MWn } \\
\text { Ton U }\end{array}$ & $\begin{array}{l}\text { Cooling } \\
\text { Time } \\
\text { Days }\end{array}$ & $\begin{array}{c}\text { Production } \\
\text { Rate, } \\
\text { Tons U/Day }\end{array}$ & $\begin{array}{c}\text { Cycles } \\
\text { Operated }\end{array}$ & $\begin{array}{c}\text { Total } \\
\text { Evaporation } \\
\text { of Water, } \\
\text { Gallons* } \\
\end{array}$ & $\begin{array}{c}\text { Time for } \\
\text { Heat } \\
\text { Evolution } \\
\text { To Decrease } \\
\text { To } 300,000 \\
\text { Btu/hr., } \\
\text { Days } \\
\end{array}$ \\
\hline $\begin{array}{l}600 \\
600 \\
600 \\
600 \\
600 \\
600 \\
600 \\
600\end{array}$ & $\begin{array}{l}60 \\
60 \\
60 \\
60 \\
40 \\
40 \\
40 \\
40\end{array}$ & $\begin{array}{l}\frac{2.5}{2.5} \\
\frac{5}{5} \\
\frac{2.5}{2.5} \\
\frac{5}{5}\end{array}$ & $\begin{array}{l}\frac{3 U-3 P u}{2 U-2 P u} \\
\frac{3 U-3 P u}{2 U-2 P u} \\
\frac{3 U-3 P u}{2 U-2 P u} \\
\frac{3 U-3 P u}{2 U-2 P u}\end{array}$ & $\begin{array}{l}\frac{125,000}{220,000} \\
\frac{170,000}{310,000} \\
\frac{170,000}{280,000} \\
\frac{225,000}{390,000}\end{array}$ & $\begin{array}{l}165 \\
250 \\
205 \\
295 \\
205 \\
260 \\
225 \\
300\end{array}$ \\
\hline
\end{tabular}

* Heat of vaporization assumed tube $950 \mathrm{Btu} / \mathrm{lb}$. of water

IV. VOLUME REDUCTION OF STORED REDOX WASTES

Since calculations indicated that decay of radioactive fission products will generate sufficient heat in the waste storage tanks to evaporate significant quantities of water, it was of interest to determine to what extent these wastes may be concentrated before becoming solid. Experiments were performed to determine the freezing point of the waste following varying degrees of concentration. The exact composition of stored Redox waste will vary somewhat with the number of cycles employed and the volumes of laboratory and other variable composition waste added. For the purpose of these experiments a synthetic waste was prepared having the concentrations quoted in the Redox Technical Manual for $2 \mathrm{U}$ and $\mathrm{Pu}$ cycles, HW \# 4 Flowsheet ${ }^{(6)}$. Only those ingredients present in gross quantities were added. Changes in the number of decontamination cycles would not change this composition significantly. Measured volumes of the synthetic waste were placed in a round bottomed flask fitted with a water cooled 


\section{DFCLLSSFFED}

condenser, and the volume reduced by boiling off water. After the desired volume of water had been removed, the bottoms were allowed to cool. Temperature at which solidification started and the volume of liquid remaining at room temperature were determined approximately. No attempt was made to measure or control entrainment. Data obtained for various volume reduction factors are shown in Table III.

Data in Table III show that a volume reduction factor of between three and four may be obtained before the thick liquor will solidify completely at room temperature, which temperature is not far from the ambient temperature of the soil suriounding the tanks. The solids formed on cooling the thick liquors obtained in these experiments were, in general, grainy and easily broken by stirring.

\section{DISCUSSION}

Calculations indicate that the total quantity of heat available from stored Redox wastes will be sufficient, particularly in processing $600 \mathrm{MWD} / \mathrm{Ton}$ uranium, to evaporate appreciable quantities of water from the storage tanks. If such water could be removed from the tanks and sent to ground through cribs a considerable saving in storage space would be made. Little is known of the deentrainment factor which might be obtained during evaporation within the tanks. However, at the low vapor velocities which would be involved, it seems reasonable to expect a decontamination factor of $10^{4}$ to $10^{5}$. Decontamination factors of $10^{6}$ to $10^{7}$ would be required to produce a cribbable condensate. Because of the very low salt content of the condensate which would be produced further decontamination, almost certainly, could be accomplished economically by use of ion exchangers. 
TABLE III

- VOLUME REDUCTION OF REDOX STORED WASTE

Composition of Simulated Waste: $1.17 \underline{\mathrm{M}}-\mathrm{NaAlO}_{2}, 1.41 \underline{\mathrm{M}}-\mathrm{NaOH}$

$$
3.84 \underline{\mathrm{M}}-\mathrm{NaNO}_{3}
$$

Batch Size: $700-800 \mathrm{ml}$.

\begin{tabular}{|c|c|c|c|}
\hline $\begin{array}{c}\text { Volume } \\
\text { Reduction } \\
\text { Factor* } \\
\end{array}$ & $\begin{array}{c}\text { Maximum } \\
\text { Boiling } \\
\text { Point, } \mathrm{C} \\
\end{array}$ & $\begin{array}{c}\text { Temperature at which } \\
\text { Solid First } \\
\text { Appeared, }{ }^{\circ} \mathrm{C} \\
\end{array}$ & $\begin{array}{c}\text { Volume of Liquid in } \\
\text { Slurry at Room } \\
\text { Temperature, } \\
\% \text { of Slurry Volume }\end{array}$ \\
\hline 2 & 119 & $\sim 65$ & 45 \\
\hline $21 / 2$ & 130 & $>100$ & 32 \\
\hline $23 / 4$ & 132 & $>110$ & 27 \\
\hline$\cdot 3$ & $\cdot 135$ & At B. P. & 18 \\
\hline 4 & -144 & At B. P. & 0 \\
\hline 6 & Became Molten & $>300^{\circ} \mathrm{C}$ & -- \\
\hline
\end{tabular}

* Based on volume of distillate collected.

In no case considered (see Table II) is the calculated heat evolution from stored Redox wastes sufficient to obtain the maximum volume reduction factors shown in Table III. To obtain maximum volume reduction either supplemental heat must be supplied within the tanks or partial concentration achieved prior to tanking. The economics of these approaches require evaluation. To remove the evaporated water from the tanks it is suggested that either the present air condensers on the tanks be modified to permit condensate take-off or provision be made to collect refluxed water in the stepped outlet from tank to condenser with provision to remove the collected water by means of a sump pump. If sufficiently low in activity the condensate could be sent directly to an underground crib. Ion exchange techniques could be used, at small cost, to further decontaminate condensates too high in activity content for cribbing.

3 
Problems connected with in-tank evaporation of stored wastes include the effect on corrosion rates of increased boiling temperature as the wastes concentrate and the behavior of large quantities of solid material within which relatively large amounts of heat are being produced.

\section{REFERENCES}

1. J. L. Schwennesen, "Calculation of Expected Heat Evolution and Radiation Intensity in Redox Waste Storage Tanks," - HW-14388, September 8, 1949.

2. H. J. Kamack, 'Fission Product Activities In Irradiated Uranium Cooled for Long Periods." - $(\mathrm{H}) \mathrm{CN}-\mathrm{S}-3475$, January 4, 1946.

3. "Hanford Engineer Works Technical Manual, Section C." May 1, 1944 .

4. P. R. Gillette, "Activity of Fission Products" HW-17415, April 14, 1950.

5. Nuclear Data, National Bureau of Standards, Nuclear Data Group. (1950).

6. "Hanford Works Redox Technical Manual, Table X-1," HW-18700, July 10, 1951.

7. R. E. Tomlinson, "Purex Process Evaluation." - HW-22888, December 10, 1951.

8. Verbal Report from B. E. Kirkendall.

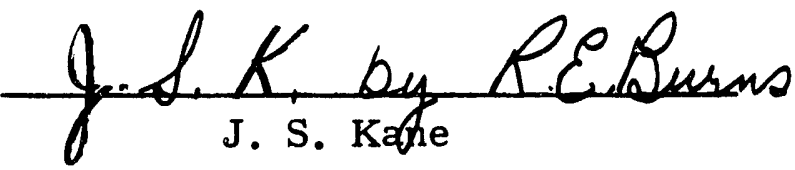

JSK, REB:dt

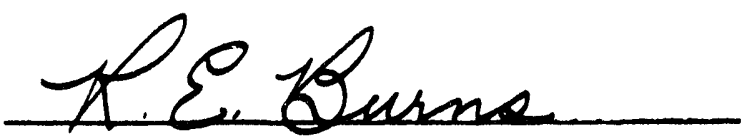

R. E. Burns 

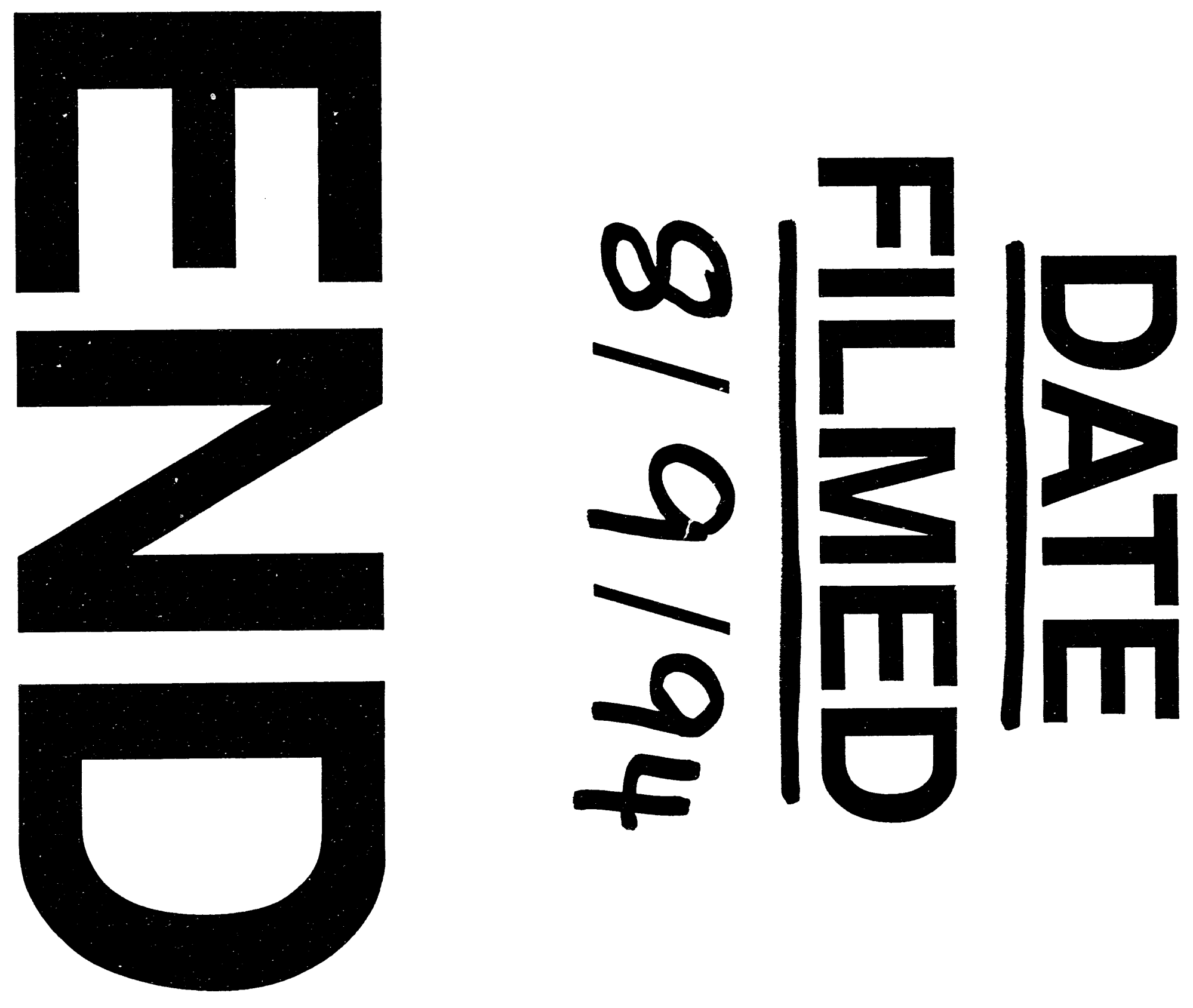


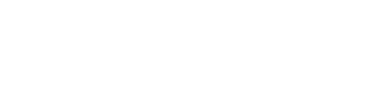

$\underline{1}$ 